\title{
FOOD CONSUMPTION AND PRODUCTION IN TEMPE LAKE, SOUTH SULAWESI, INDONESIA
}

\author{
M. Saleh S. Ali*, Amrullah Majika, Darmawan Salman \\ Department of Socio-Economic of Agriculture, Faculty of Agriculture, Hasanuddin University, \\ Makassar, Indonesia \\ *Corresponding author: E-mail: saleh.assofie@ gmail.com
}

Citation: Ali, M.S.S., Majika, A., Salman, D., 2017. Food Consumption and Production in Tempe Lake, South Sulawesi, Indonesia. J. Asian Rur. Stud. 1(1): 43-52

\begin{abstract}
Challenges in providing sufficient food is a society problem and it will exist along with human civilization history.In this modern civilization, when the population reach more than 7 million people in the world, food consumption and production become a civilization problem and nature becomes a victim of it. Nowadays, almost 1 million people facing undernutrition and malnutritionThis study aimed to identify the pattern of food consumption and production in Tempe Lake, the biggest lake in the province or in Sulawesi island. A fieldwork conducted on February 2016 at Laelo Village (Kelurahan Laelo) that belongs to Tempe Sub-district (Kecamatan Tempe). Total respondents in this study were 72 people who were selected randomly from those have use the lake as main source of livelihood. Some informants who know more about the lake were also interviewed. Data gathered mainly about land use of the lake during dry season and wet (flood) season, and food consumption and production pattern, This research found that fish production of the lake has decreased significantly in the last 20 years due to sedimentation, overfishing and environmental contamination. People consumed various foods for their dietary but mostly consuming rice that they purchased from market and fish and vegetables from the lake. There was no different in amount of rice and fish consumed during wet and dry season.
\end{abstract}

Keywords: Tempe Lake; Food Production; Food Consumption

\section{Introduction}

Challenges in providing enough food is a society problem and it will exist along with human civilization history. In old civilization, when population was still in small amount and the nature was in a perfect condition to support human needs, food was not a problem yet, because people just gathered food that available from the nature. At that time, nature became 'a good mother' for human (Verhagen, 2008). However, in this modern civilization, when the population reach more than 7 million people in the world, food consumption and production become a civilization problem and nature becomes a victim of it. Nowadays, almost 1 million people facing undernutrition and malnutrition (FAO, 2011).

By 2050, when the world's population will reach 9.1 billion ( $34 \%$ higher than today), food production has to be increased to up to $70 \%$ by using the limited natural resources especially land (Freibauer et al., 2011, Godfray et al., 2010). In this situation, we must call for a new approach that ensures success and sustainability under this new set of constraints that we may call it as "post-modern" agriculture (Uphoff, 2007) which 
draws more effective on production ecology principles to improve the productivity and efficiency of agriculture while reducing negative environmental impacts. Dutch Farm Experience (2014) identified nine traditional elements of in post-modern sustainable dairy farming, namely build on farmers' initiatives and knowledge, re-establish importance of soil-plant-animal-manure cycle, focus on optimization rather than maximization of a single product, re-diversifying farmer's work and income, re-valuing direct marketing and urban-rural linkages, re-valuing the link between farming and natural environment, re-valuing local \& dual purpose breeds, re-linkage between crop \& livestock farms, and re-valuing medicinal plants.

Issue of food sustainability was first stressed in Agenda 21 (Du Plessis, 2001) which stated that unsustainable consumption and production patterns were the main cause for global environmental deterioration. The Food and Agriculture Organization (FAO) defines sustainable consumption and production in food and agriculture is a "consumerdriven, holistic concept that refers to the integrated implementation of sustainable patterns of food consumption and production, about the carrying capacities of natural ecosystems. It requires consideration of all the aspects and phases in the life of a product, from production to consumption, and includes such issues as sustainable lifestyles, sustainable diets, food losses and food waste management and recycling, voluntary sustainability standards, and environmentally friendly behaviors and methods that reduce adverse impacts on the environment and do not jeopardize the needs of present and future generations. Sustainability, climate change, biodiversity, water, food and nutrition security, right to food, and diets are all closely connected."

In this study, we analyze of consumption and production by taking Tempe Lake in Wajo District as a research site. In this analysis, we describe first how the lake utilized and then presents consumption and production pattern of the community.

\section{Method}

This study is a case study about the patterns of food consumption and production at Tempe Lake. Filed work conducted in February 2016 which focused on Laelo Village (Kelurahan Laelo) of the Tempe Sub District (Kecamatan Tempe). The Laelo Village is about 5 kilometers from the City of Sengkang, the capital city of Wajo District. Total respondents of this study were 72 people, who were randomly selected from those who have used the lake as main source of livelihood. Beside the respondents, we interviewed also some informants suchmatoa tappareng (guard of the lake), some elder peoples in the community,head of a hamlet, and head of the village. Data gathered mainly about the utilization of thelake (during dry season and wet (flood) season) and Food consumption and production patterns.

\section{Results and Discussion}

\subsection{Ecology of Tempe Lake}

Tempe Lake locates about $192 \mathrm{~km}$ from Makassar (the capital city of South Sulawesi) to the north direction. The lake belongs to three districts namely Wajo District, SidenrengRappang (Sidrap) District, and Soppeng District with total size of 47.800 hectares. About 70 percent of the lake area belongs to Wajo District. Geographically, the Tempe Lake located at $4^{\circ} 00^{\prime} 00 \|-4^{\circ} 15^{\prime} 00^{\prime \prime}$ SL and $119^{\circ} 52^{\prime} 30^{\prime \prime}$ $120^{\circ} 07^{\prime} 30^{\prime}$ ' EL. The rainfall in the lake was $1.400-1.800 \mathrm{~mm} /$ year. Water depth in the 
middle of the lake during wet season was 3 meters, while in dry season was only 1 meter. During the dry season, the area of the lake was only 1000 hectares, while in normal condition the lake area was 15.000-20.000 hectares.

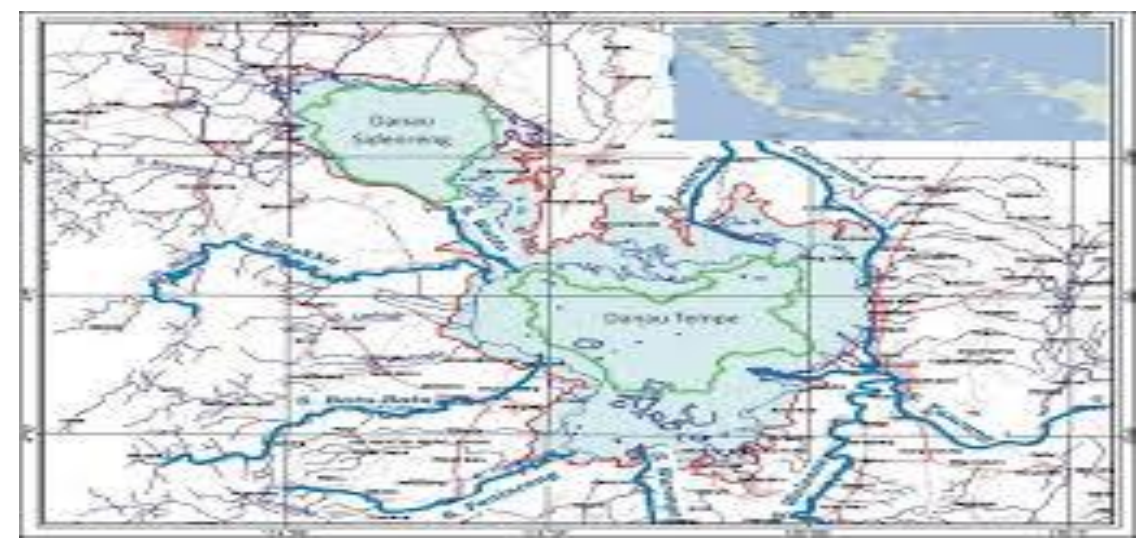

Map of Tempe Lake

There are some rivers runs down to and become the source of sedimentation of the lake, namely (1) Bila River that covered by 3 watersheds from Enrekang, Sidrapand Wajo Districts. (2) Walanae River covered by watershed from Soppeng, Bone, Maros and Wajo Districts, and (3) Some small rivers such as Wette'e River, Batu-Batu River, Waronge River, and Tancung River that also contribute to sedimentation of Tempe lake.

A research done by JICA (1993) pointed out that every year the sedimentation level was about $15-20 \mathrm{~cm}$ and it tended to increase. According to report by BAPEDAL Region III (2000) that when the sedimentation level continuously increased, it predicted that $100-200$ years from now, the Tempe Lake will disappear .(Anonymous, 2016). The climate around the lake was characterized by tropical monsoon with clear distinction between dry season and wet season. Wet season was on March - July, while dry season on August - February. During dry season when the water level in the lake decrease significantly, land around the lake has been used by local community to grow rice and other food crop such corn, beans, etc. Number of population inhabiting around the lake were about 31.800 people who worked as fishermen, farmers, cattle raisers, silk craftsmen, traders, and government officials.

\subsection{Utilization Pattern of Tempe Lake}

\subsubsection{Utilization as Agricultural Land}

During dry season the water level in the lake has decreased significantly and creating an extensive land that can be used to grow seasonal crops such as corn, rice, soybean, water melon, etc. This land locally named as Koti Land. Koti in Buginese language means "taking something from a box or container". Therefore, Koti Land means a piece of land that acquired through a lottery, by taking random number from a box. This number indicates the location of land.

There was no exact measurement numbers of Koti Land, but it was predicted about 12.000 hectares per year. According to some informants that everyone who works as fishermen and farmers has similar right to cultivate Koti Land through a lottery of 1500 
$\mathrm{m} 2$ per person. For those who have won the lottery of Koti Land but did not cultivate it, they can sell his cultivation right to others or give to other farmers to cultivate it through share crop system.

Based on its site, Koti Land is divided into four categories. The first class is called Tanah KotiLangga I (First Grade Koti Land). This land at upper outskirts of the lake, around 100 meters from the edge of the lake. The second is called Tanah Koti Langga II (Second Grade Koti Land) that located around 100-200 meters from edge of the lake. Third is Tanah Koti Langga III (Third Grade Koti Land) which was about 200-300 meters from the lake edge; and Fourth is called Tanah Koti Langga IV which was close to the water lake. According to District Regulation of Wajo No. 9 Year 2013, the retribution of the first grade Koti Land was Rp. 60.000/Ha/year, The second grade Koti Land was Rp. 30.000/ha/year, The third grade was Rp. 20.000/ha/year, and the fourth grade was Rp. 15.000/ha/year.

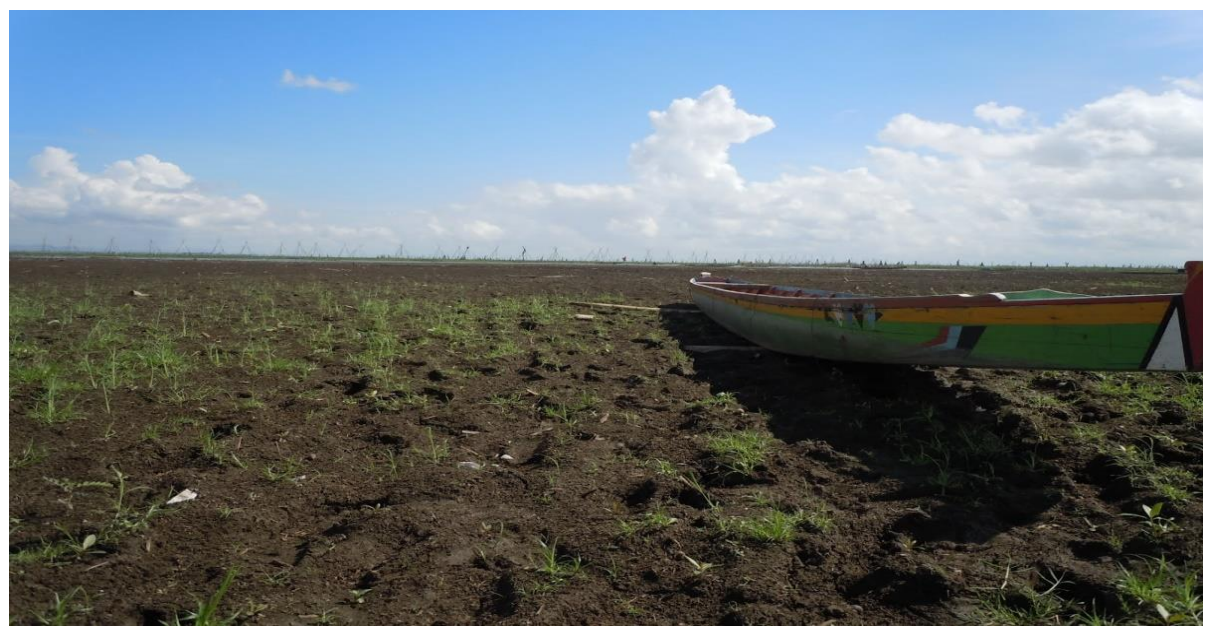

Photo: Koti Land (Land that emerges when the water level of Tempe Lake decreased).

\subsubsection{Utilization as Fishing Ground}

In the past, Fishing ground or catching area for fish in Tempe Lake was only known 2 types namely fishing ground owned by royal family while the other was utilized by common people (Free Fishing Ground). Nowadays, several types of fishing grounds have been seen in the lake.

Akkarung. Akkarung fishing ground is an area under control or owned by royal family, The size of the akkarung was fix. Right to utilized this area including the land that occured when the water in the lake decrease was solely belonged to the royal family. The royal family usually gavehis right to utilized the akkarung to other people by share or rental system.

Cappeang. This area located close to akkarung fishing ground. It was usually near to edge of the lake. In the past, this area were given to official of the kingdom, but this time the area is under control of local authority (Pemda) and one who would like to occupy this area has to apply by paying sum of money for 3 years period.In the past, when the lake water was in stable condition, the cappeang was used to catch fish all year around. But now, this fishing ground will disappear when the lake water run away in dry season. 
Palawang, is a catch area after Cappeang, located about 100 meters from edge of the lake (sipattembakeng $=$ one shoot distance) with clear boundaries indicated by belle (bamboo pench) with high of 1.25 meter. Right to utilize a palawangwas also gotten through auction held by local authority.

Bungkatoddo'is fishing ground located close to the center of the lake. This area is quite deep and therefore cathing can be done every day. Bungka toddo created by sticking a number of bambooto hold water hyacinth (enceng gondok = Eichorniacrassipes). Since many bamboo used to catch the water hyacinth, the bungka toddowas fulfilled by floating hyacinthand became a good place for fish to looking for food and as shelter. Size of a bungka toddo averagely was $125 \mathrm{~m}$ x $125 \mathrm{~m}$. Right to utilize the bungka toddowas through auction held by the district authority. According to an informant, the auction price of a bungka toddo could be up to Rp. 150 million/year, depend on its size.

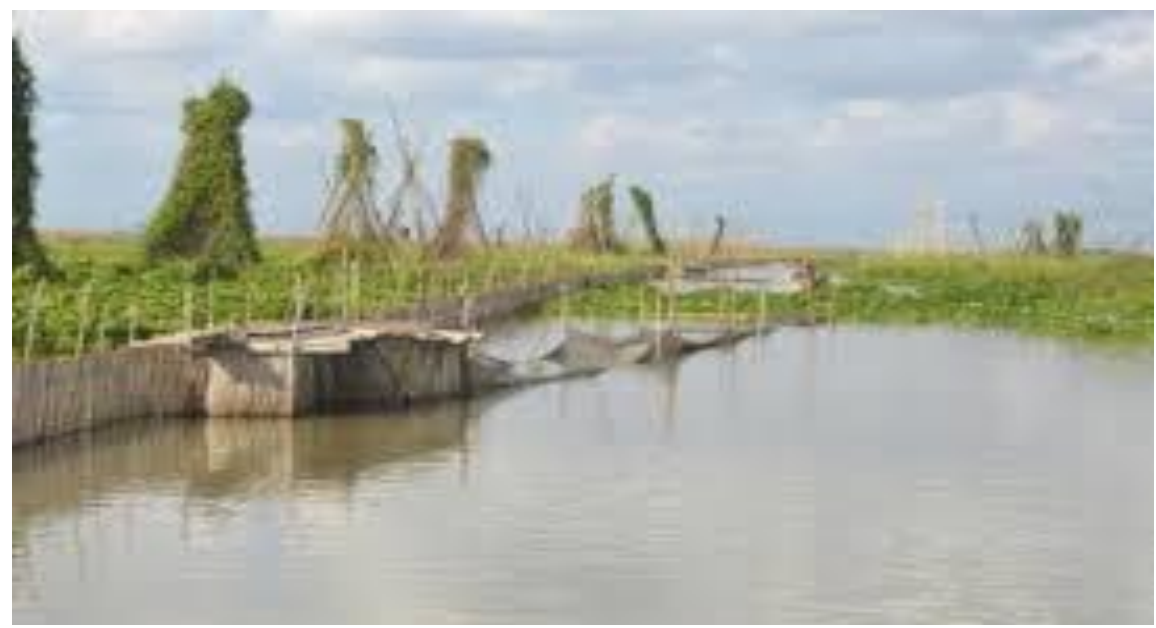

Photo: Bungka Toddo

Salo'-salo' (small rivers). Around the Tempe lake, there were so many salo-salo as place for fish to breed. These salo-salo occurred only in dry season. Some salo-salo were formed naturally and some were man-made. Right to used this fishing ground is also obtained through auction held by local authority.

Free Fishing Ground, is an area outside of the above mentioned fishing ground and anyone can catch fish in this area. Its location could be at the middle of the lake or in between bungka toddo, palawang or cappeang. Although everyone can catch fish in this area but they have to obey custom regulation such as they are not allowed to catch fish starting from sunset of Thursday until 2 o'clock the next day or Friday (after Jumat Pray).

\subsection{Food Production in the Lake}

\subsubsection{Food Crops Production}

Food crops in Tempe Lake were cultivated only during dry season. The majority of farmers $(97.22 \%)$ planted corn, while the rest of them $(2.78 \%)$ planted rice. The average of corn production was $4.023 \mathrm{~kg} /$ household. Productivity of corn reached 8.920 $\mathrm{kg} / \mathrm{hectare}$ while rice was $6.100 \mathrm{~kg} / \mathrm{hectare}$. 


\subsubsection{Fish Production}

The Tempe Lake is very rich with endemic freshwater fishes such as Cyprinuscorpio, Osteochillushassellti), Ophiocephalusstriatus, Tricogasterpectoralis), Glosogobiusguiris), Helostomatemmicki), and Oreochromisniloticus.

At the end of the 1960s, Tempe Lake was the biggest freshwater fish producer in Indonesia. In 1948 - 1969, yearly fish production was $37.000-40.000$ tons of various types of fish. In 1999 and 2000, the fish production was 17.077 tons and 17.200 tons. This production had decreased significantly up to 8.475 tons in 2015 (see Table below).

Table 1. Fish Production of Tempe Lake

\begin{tabular}{lll}
\hline No. & Period (Year) & Production (Tons) \\
\hline 1. & $1948-1969^{*}$ & $37.000-40.000$ \\
2. & $1999^{*}$ & 17.077 \\
3 & $2000^{*}$ & 17.200 \\
4. & $2013^{* *}$ & 11.794 \\
5 & $2014^{* *}$ & 11.204 \\
$6 . \quad 2015^{* *}$ & 8.475 \\
\hline Source: \\
*Yasmin (2015). \\
**Tempe Sub District in Numbers, 2016.
\end{tabular}

Table 1 showed that the fish production in Tempe Lake has decreased from year to year as the result of sedimentation, overfishing by trawl and environmental degradation.

\subsection{Food Sources}

Food sources in the lake area are generally from the fish catching in the lake and food crop production from Koti Land. The food that communities cannot produce it, they purchase it from the local market, small market, or through trader who sells food from door to door.

\subsubsection{Rice}

Almost all farmers in the study area are obtaining rice as their staple food from the market and only a small percentage of farmers obtaining rice from farming. Selection of food sources can be seen from the frequency of food purchasing from the market. The percentage of respondents who frequently buy rice from the market was $97.22 \%$.

There is no difference between source of getting rice in the dry season and in the wet season. The percentage of respondents who frequently buy rice from the market in the dry season is similar with percentages in the wet season. Since environmental conditions in the study area is not adequate for planting rice, therefore people in the Tempe Lake area are generally fulfilling their rice needs from the nearby market.

\subsubsection{Vegetable}

Vegetable, as one of the food source at Tempe Lake community, is mainly from the market and from the nearby neighborhood area. The respondents of vegetable as food sources can be seen from the frequency of vegetables purchase from the market. The percentage of respondents who acquire their vegetables from the market is higher than respondents who get their vegetables supply from their natural environment. 
During the dry season, most of the vegetable source is coming from the market. In detailed, in the dry season, more respondents $(54.17 \%)$, obtained their vegetables from the market, while in the wet season, most of the respondents $(86.11 \%)$ do not buy their vegetables from the market. The reason is that during the wet season vegetable availability in their region is overflowing, especially for certain vegetable type such as water spinach (Ipomoea aquatica), as the result of flooded in some area which makes these plants grow lavishly. Therefore, large quantities of vegetable suppliers in the Tempe Lake area have caused the community reducing the amount of vegetable purchases from the market.

The source of vegetable during the dry season for respondents who lives near the mainland is mainly from the market, while for respondents who lives far from the mainland are rarely purchasing their vegetables from the market. During the dry season, farmers who live near the mainland are frequent $(83.33 \%)$ get their vegetables from the market. The reason is that their land condition in the dry season is experiencing drought more quickly than respondents who live far from the mainland, which caused spinach water plants grow lesser and the vegetables supply is declining. Respondents who are living far from the mainland in general $(66.67 \%)$ still seldom buying vegetables from the market during the dry season. The reason of this condition is because most of their area is still flooded, so that certain vegetable population is still enough to meet their needs.

The source of vegetables during the wet season for respondents who either live close or far from the mainland land is rarely from the market. In general, during the wet season, there are $70 \%$ farmers in the area close to the mainland are seldom obtaining their vegetables from the market. Similarly, most the farmers who live far from the mainland accounted for $97.60 \%$ who do not purchased vegetable from the market. The high percentage of people who do not obtain their vegetables from the market is due to the high vegetable availability in both regions.

\subsubsection{Fish}

Tempe Lake is known as the region that produces plenty of fish that consumed by nearby communities and other regions. The community around the Tempe Lake area has convenience in getting easier fish as their protein source to meet their household needs. The huge number of fish in the region has become the main food source to fulfill fish supplies for communities in Tempe Lake.

During the dry season, farmers in Tempe Lake are seldom to purchase fish from the market. There are $97.22 \%$ people from Tempe Lake community who are rarely purchasing fish from market because most of the consumed fishes are coming from the Tempe Lake. There is no difference in fish purchasing pattern between communities that lives nearby and far from the mainland because both of these communities have similar easy access to the Tempe Lake.

\subsection{Food Consumption}

Tempe Lake community consumes various types of food as their source of carbohydrate, protein, fat, vitamin, and mineral. Carbohydrate sources available in the area are rice, corn, and rhizomes. While for protein sources, the households in Tempe Lake consume fish, eggs, and meat. Orange, papaya, olive (Lansiumdomesticum), and 
rambutan (Nepheliumlappaceum) are local, seasonal fruit that's available at the source of vitamins and minerals for the community on Tempe Lake. Banana is available the whole season for community's vitamin and mineral sources. Vegetables that commonly consumed by the community are spinach, egg plant, and green long beans (Vignasinensis L.).

\subsubsection{Rice Consumption}

Rice is the staple food for community in the Tempe Lake area that mostly and frequently consumed to fulfill the carbohydrate needs. Rice has a relatively high carbohydrate and become the main source of energy in addition to other food sources. As community's staple food, rice is consumed in bigger proportions than other food sources such as corn and rhizomes. For this community, eating rice is obligatory daily food that consumed more than once in a day. Rice must be available every day in a household and rarely replaceable by other carbohydrate sources. The entire community in Tempe Lake consumes rice as their staple food in dry and wet season

\subsubsection{Fish Consumption}

Fish is the most consumed in the area of Tempe Lake along with chicken, egg, and meat in limited quantities and only in certain days or occasions. Fish consumption is more than any other animal food sources. This is because its availability and accessibility in obtaining fish is bigger than other animal food sources.

Fish consumption in the dry season is frequently occurring in the Tempe Lake communities, both in the area that is near and far from the mainland. There is $96.70 \%$ of communities live near the mainland who are very frequently consuming fish and only $3.30 \%$ of communities who do not consume fish in their daily basis. The entire communities who live far from the mainland are very frequently consuming fish in their daily basis and the communities consume more fish during the wet season than the dry season. These phenomena are occurring both in the area that is close and far from the mainland. During the wet season, a free fishing area in Tempe Lake is getting larger, which provides daily access for community to catch more fishes and ensures community's fish consumption.

\subsubsection{Vegetable Consumption}

Vegetables as a protein source that consumes by community in Tempe Lake are tofu, Tempe, beans, and its derivative products. This food source is not consumed in big quantities and only as a side dish along with rice and fish. During the dry season, vegetable is not for daily consumption. Most of consumption frequency is in frequent category ( 4 to 5 times a week) and occasionally ( 2 to 3 times a week). While during the wet season, only a small proportion of community consumes vegetables.

Vegetable consumption percentage of community in Tempe Lake is relatively high, particularly community that lives far and close to the mainland. The percentage of respondents that consumed vegetables in a very frequent category is $50,00 \%$. The majority of respondents $(53,33 \%)$ who live both near and far the mainland has a very frequent category in vegetable consumption. The high vegetable consumption frequency is due to easier access to vegetable sources around the area. Easier vegetable access is supported by vegetable availability in the market and at the surrounding neighborhood. 


\subsubsection{Fruits Consumption}

Fruits consumption frequency in the Tempe Lake area varies by several categories, namely very frequent, frequent, and rare. The variations are based on community's residential location. Fruit consumption of community in Tempe Lake in majority is 47,22\% (frequent category). Wajo District, where the community of Tempe Lake, located has various local fruit production. This condition has created easy access to community in obtaining fruits for their consumption. Although in general, people do not grow their own fruits, but they have better access to the market to purchase fruits. Housewives also have easy access to fruits from the market because they are also having responsibility to sell the fish every day to similar market.

This study shows that people who live far from the mainland are more frequently consuming fruits than those who are living near the mainland. People who live far from the mainland are closer to the free fishing area; therefore they can get fish at any time. When the fishing activities are carried out on a daily basis, then the fish catches should be marketed every day. This situation gives the opportunity and ease market access to fruits for housewives at any time.

\subsection{Consumption Expenditure}

Public expenditure for food consumption was fulfilled from two main sources of incomes, namely as farmers and fishermen or fishing on the lake. As a farmer, in general $(59.52 \%)$ has income around 5 to 10 Million Rupiah per season. As a fisherman, in general (65.85 \%) has income around 1.5 to 2 Million Rupiah per month. Food consumption expenditure of community in Tempe Lake in general (68.06\%) ranges between Rp. 300,000, - to Rp. 600,000, - per month. Low public expenditure is caused by insufficient income to be able to purchase vegetables and fish. Only a small percentage (6.94\%) of people who have food expenditure that is accounted under Rp. 300,000 , - and some of them (25.00\%) have food expenditure that is accounted above Rp. 600,000,- .

\section{Conclusion}

Tempe Lake is a very potential resource that produces fish and agricultural products such as corn and rice. This lake was once the largest producer of freshwater fish in Indonesia, but due to the siting and environmental pollution the lake fish production has decreased every year. The utilization of Tempe Lake is affected by the seasons. In the wet season the water level of the lake is high enough to use as a fishing area. The district through an auction process regulates larger fishing zones like Bungka Toddo area, Palawang area, and Salo-Salo area. While the zone outside the fishing area becomes free fishing areas, where the package fishermen catches their fish.In the dry season when the water level of the lake receded, the land arises from the lake that called Koti Land. The Pakkoti farmers plant their annual crops, especially maize and rice, in utilizing this land. The main production of Tempe Lake is various types of freshwater fish. However, the number of freshwater fish production continues to decline. The lake silting, overfishing and environmental pollution are mostly the cause of this decrease. Tempe Lake community consumes various types of foods, such as rice, maize, fish, vegetables, and fruits. Rice is the staple food consumed in bigger portions than any other type of foods. For this community, eating rice in a daily basis is essential. Fish 
consumption of this Tempe Lake community is quite high and there is no difference in the fish consumption pattern during the dry season and the wet season. This is understandable because of the community has easy access to this food. Most of the vegetables are obtained from vegetables such as water spinach (Ipomoea aquatica) that is widely available around the lake and also legumes grown on Koti Land. Banana is the type of fruit that is mostly consumed by this community. There are differences in the fruit consumption pattern among the residents who live near and far from the Lakeshore. Those who live close to the Lake consume more fruit than those who lives far. Income of Koti Land's farmers ranges between Rp. 5 Million to 10 Million per season, while Pakkaja Fishermen earn between Rp. 1.5 Million to Rp. 2 Million per month. Low public spending in food consumption is caused by the lack of income allocation in purchasing vegetables and fish.

\section{References}

Annonimous 2016. "Save Our Tempe Lake". https://laketempe.wordpress.com/ environmental-degradation/

Du Plessis, C. (ed.) 2001. Agenda 21 for Sustainable Construction inDeveloping Countries - First Discussion Document CSIR, Pretoria and CIB, Rotterdam.

Dutch Farm Experience, 2014.Nine traditional elements in post-modern sustainable dairy farming.http://www.dutchfarmexperience.com/nine-traditional-elementspost-modern-sustainable-dairy-farming/, Download 8 December 2016.

Foster, C., Green, K., Bleda, M., Dewik, P., 2007. Environmental impacts of food production and consumption: final report to the Department for Environment Food and Rural Affair. FAO Publication

Freibauer, A., Mathij. E., Brunori, G., Damianova, Z., Faroult, E., Gomis, J.G., O'Brien,L., Treyer, S., 2011. Sustainable food consumption and production in a resource-constrained world.The $3{ }^{\text {rd }}$ SCAR Foresight Exercise.

Godfray, H. and Charles J., Beddington, John R., Crute, Ian R., Lawrence Haddad, David Lawrence, James F. Muir, Jules Pretty, Sherman Robinson, Sandy M. Thomas, Camilla Toulmin, 2010. Food Security: The Challenge of Feeding 9 BillionPeople. Science 12. Vol. 327, Issue 5967, pp. 812-818.

Goodman,A. H., and Leatherman, T. L. (eds.).,1998 Building a New Biocultural Synthesis: Political-Economic Perspectives in Biological Anthropology. Ann Arbor:

Uphoff, N., 2007. "Envisioning 'post-modern agriculture'-A Thematic Research Paper."Cornell University, Ithaca: Accessed through WAASAN Website.

Verhagen, F.C. 2008. "Worldviews and Metaphors in The Human-Nature Relationship: An Eco-linguistic Exploration Through the Ages." Language \& Ecology. Vol. 2 no. 3.

Walker, P., 1998. Politics of Nature: An Overview of Political Ecology. Capitalism.Nature Socialism. Volume 9(1):131-144

Yasmin, 2015. Livelihood of Community in Tempe Lake and Fisheries Indigenous Knowledge in Ecological and Political Studies.A Field Report. 